\title{
ARTICLE 4 OF THE ECHR AND THE OBLIGATION OF CRIMINALISING SLAVERY, SERVITUDE, FORCED LABOUR AND HUMAN TRAFFICKING
}

\author{
Vladislava Stoyanova*
}

\begin{abstract}
This article addresses the interaction between international human rights law and national criminal law as exemplified and revealed in relation to the abuses of slavery, servitude, forced labour and human trafficking (THB). First, I point out the mismatch between the interpretative techniques of international human rights law and national criminal law. The reportedly low numbers of prosecutions and convictions for abuses against migrants has gathered increasing attention. As a reaction it has been suggested that the definitions of THB and of slavery, servitude and forced labour (where the latter have been specifically criminalized) have to be expansively construed. These suggestions ignore basic criminal law precepts. Criminal law has to remain faithful to the principle of legal certainty and to the rights of the accused which ban expansive interpretations. It is human rights law which celebrates liberal interpretations of concepts for the purpose of holding states internationally responsible for their failures to protect. Despite the difference in their interpretative standpoints, there is a clear interaction between these two fields of law. A manifestation of the interaction is that the ECHR obliges states to criminalize the abuses falling within the material scope of Article 4 of the ECHR. I argue that many states have failed to fulfil this obligation since the focus has been predominantly placed on the criminalisation of THB. This leads to failures to address abuses where there are no elements of recruitment, transportation, transfer etc. by means of deception/coercion. I also demonstrate that Article 4 of the ECHR obliges states to incorporate in their domestic criminal laws clear definitions of crimes intended to address the abuses falling within the scope of Article 4. An obligation which many states have failed to fulfil since they have directly copied the international definition of THB and/or the human rights definitions of slavery, servitude and forced labour, without further establishing the elements of the crimes at domestic level. Finally, I suggest that there needs to be a better articulation of the distinctions between different crimes meant to addresses abuses falling within the ambit of Article 4 of the ECHR.
\end{abstract}

\section{Keywords}

Slavery, Servitude, Forced labour, Human trafficking, ECHR Article 4, Positive

\footnotetext{
Doctoral candidate, Faculty of Law, Lund University, Sweden. Contact vladislava.stoyanova@gmail.com or vladislava.stoyanova@jur.lu.se. This article forms part of my PhD project which examines inter alia states' positive obligations under Article 4 of the ECHR. I would like to thank Prof. Gregor Noll for his constant support and assistance. I would like to also thank Julia Planitzer and the anonymous reviewers for their comments on earlier versions of this article. Responsibility for the views expressed remains mine.
}

Copyright $\odot$ the Author(s).

This work is licensed under a Creative Commons Attribution-NonCommercial-NoDerivs 3.0 License. 
human rights obligations, Siliadin v France, Rantsev v Cyprus, $\mathrm{CN}$ and $V v$ France, $\mathrm{CN} v$ United Kingdom

\section{Introduction}

Until recently, Article 4 of the Convention for the Protection of Human Rights and Fundamental Freedoms (ECHR or Convention) was a provision rarely invoked. Article 4 has, however, sprung into life in light of the abuses to which migrants in host European countries are being subjected. As a result, the European Court of Human Rights $(E C t H R)$ has delivered a couple of judgments on Article 4. In Siliadin v France, the Court held that 'the member States' positive obligation under Article 4 of the Convention must be seen as requiring the penalisation and effective prosecution of any act aimed at maintaining a person in [...] a situation [of slavery, servitude or forced labour].' The Court concluded that 'slavery and servitude are not as such classified as offences under French criminal law', ${ }^{2}$ as a result of which Siliadin was not able to see those responsible for the wrongdoing convicted under criminal law. In $\mathrm{CN} v$ France, the ECtHR reiterated that 'States are required to put in place a legislative and administrative framework that prohibits and punishes forced or compulsory labour, servitude and slavery'. In $\mathrm{CN} v$ The United Kingdom, the ECtHR again emphasised that the Government was under a positive obligation to enact domestic law provisions specifically criminalising the conduct prohibited by Article $4 .{ }^{4}$ In Rantsev $v$ Cyprus, trafficking in human beings $(T H B)$ was found to fall within the scope of Article 4. ${ }^{5}$ Accordingly, criminal law measures intended to punish traffickers also form part of states' positive obligations under the ECHR. ${ }^{6}$

In light of the above cited judgments, it is clear that states have the positive human rights obligation to criminalise abuses falling within the material scope of Article 4. ${ }^{7}$ There has been, however, little consideration of the implications

\footnotetext{
Siliadin v France [2005] VII Eur Court HR 333, para 112 (Siliadin).

2 Ibid, para 141.

$3 \mathrm{CN}$ and Vv France (European Court of Human Rights, Chamber, Application No 67724/09, 11 October 2012), para 105.

4 CN v United Kingdom (2013) 56 EHRR 24, para 66.

5 Rantsev v Cyprus (2010) 51 EHRR 1, para 282 (Rantsev).

6 Ibid, paras 284, 290.

7 Besides human rights law, the obligation of criminalising slavery, servitude, forced labour and THB has another source. There are a number of transnational criminal law treaties which oblige
} 
flowing from this positive obligation for the national substantive criminal law. I draw attention to the following implications. First, in the ample literature on THB and in the existing literature on slavery, servitude and forced labour, arguments are advanced for expansive interpretation of the definitions of slavery, servitude, forced labour and THB. These arguments are a response to the reportedly low numbers of prosecutions and convictions. However, the difference in terms of means of interpretation applicable in human rights law and in national criminal law has remained ignored. There is little regard to the principle of legal certainty, which bans expansive interpretation of the definition of crimes. In contrast, human rights law celebrates progressive interpretations. In this article, I point out the mismatch between the interpretative techniques of international human rights law and national criminal law. I illustrate how this mismatch plays out in the context of the abuses of slavery, servitude, forced labour and THB.

Despite the difference in their interpretative standpoints, there is a clear interaction between these two fields of law. A manifestation of the interaction is that the ECHR obliges states to criminalise the abuses falling within the material scope of Article 4 of the ECHR. The second argument that I develop is that many states have failed to fulfil this obligation since the focus has been predominantly placed on the criminalisation of THB. This leads to failures to address abuses where there are no elements of, inter alia, recruitment, transportation, transfer by means of deception or coercion.

Finally, I submit that states' obligations under Article 4 are not limited to the simple introduction of criminal offences. Article 4 imposes certain standards as to the quality of the national substantive criminal law. I demonstrate that many states have failed in this respect, since they have directly copied the international definition of THB and/or the human rights definitions of slavery, servitude and forced labour, without further establishing the elements of the crimes at a domestic level. I also add that states might be found in violation of their obligations under Article 4 not only when national crimes are obscurely defined, but also when they are haphazardly distinguished.

I take the following steps in order to develop my arguments. I lay out how the ECtHR has developed criminalisation as an aspect of states' positive human rights obligations (Section 2). Then, I emphasise the different rationales and interpretation techniques applicable in international human rights law and in

states to criminalise these practices. See generally N Boister, An Introduction to Transnational Criminal Law (2012). 
national criminal law (Section 3), in order to finally address the major questions ensuing from the obligation to criminalise: are states under the obligation to have the specific criminal law labels of slavery, servitude and forced labour (Section 4)? Are states under the obligation to define slavery, servitude, forced labour and THB in any particular way in their national criminal law? In light of states' positive obligations under Article 4, what standards must substantive national criminal law live up to (Section 5)?

When addressing these questions, I concentrate on abuses against migrants. The reason for the latter choice is that it is precisely abuses against migrants in host states which have enlivened the questions of how slavery, servitude, forced labour and THB are to be defined in the context of criminal law and human rights law. I rely on judgments of the ECtHR and of national courts as well as national legislation to achieve this article's objectives. The relatively recently published reports of the GRETA play important facilitative role for gaining insights into the national criminal legislation of the Council of Europe's member states. ${ }^{8}$

Proper engagement with the above questions requires initial familiarity with the definitions of the concepts falling within the ambit of Article 4. Slavery is defined in the 1926 Slavery Convention as 'the status or condition of a person over whom any or all of the powers attaching to the right of ownership are exercised.' The ECtHR has endorsed this definition for the purpose of interpreting slavery under Article 4 of the ECHR. ${ }^{10}$ The ECtHR has taken the ILO definition of forced labour as a starting point for its own interpretation of the concept. ${ }^{11}$ The 1930 ILO Forced Labour Convention defines forced labour as 'all work or service which is exacted from any person under the menace of any penalty and for which the said

8 GRETA monitors the implementation of the Council of Europe's Trafficking Convention by the state parties. See Council of Europe Convention on Action Against Trafficking in Human Beings, 16 May 2005, CETS 197, Art 36(1) (Trafficking Convention).

9 Slavery Convention, 25 September 1926, 60 LNTS 254, Art 1.

${ }^{10}$ In Siliadin, the ECtHR referred to the definition of the 1926 Slavery Convention. It interpreted it as requiring exercise of a 'genuine right of legal ownership' and reduction of the person to the status of an 'object'. The Court's reference to 'legal ownership' as a required element of slavery gave rise to criticism. See J Allain, 'Rantsev v Cyprus and Russia: The European Court of Human Rights and Trafficking as Slavery' (2010) 10 HRLR 546. In $M$ and Others $v$ Italy and Bulgaria, the Court changed its language by discarding the requirement for 'legal ownership' and simply referring to slavery as an 'exercise of a genuine right of ownership and reduction of the status of the individual concerned to an "object". See M and Others $v$ Italy and Bulgaria (2013) 57 EHRR 29, para 149.

11 Van der Mussele v Belgium (1983) 70 Eur Court HR, Ser A, para 32; Siliadin [2005] VII Eur Court HR 333, para 116; Stummer v Austria (2011) 54 EHRR 11, paras 117-18. 
person has not offered himself voluntarily.' ${ }^{12}$ The ECtHR defined servitude as a 'particularly serious form of denial of freedom.' ${ }^{3}$ Servitude in addition to the obligation to perform certain services for others' also includes 'the obligation for the "serf" to live on another person's property and the impossibility of altering his condition. ${ }^{14}$ In $C N$ and $V v$ France, the Court further clarified that:

the fundamental element which distinguishes servitude from forced or compulsory labour, within the meaning of Article 4 of the Convention, consists in the feeling of the victims that their condition is unchangeable and that the situation is not likely to improve. ${ }^{15}$

As to the definition of THB, in Rantsev $v$ Cyprus and Russia the ECtHR held that THB under Article 4 of the ECHR is to be defined in the same way as it is defined in the Council of Europe Convention on Action against Trafficking in Human Beings (Trafficking Convention). ${ }^{16}$ The latter convention stipulates that:

[t]rafficking in human beings' shall mean the recruitment, transportation, transfer, harbouring or receipt of persons, by means of the threat or use of force or other forms of coercion, of abduction, of fraud, of deception, of the abuse of power or of a position of vulnerability or of the giving or receiving of payments or benefits to achieve the consent of a person having control over another person, for the purpose of exploitation. Exploitation shall include, at a minimum, the exploitation of the prostitution of others or other forms of sexual exploitation, forced labour or services, slavery or practices similar to slavery, servitude or the removal of organs. ${ }^{17}$

The above outlined definitions delineate the scope of the rights protected under Article 4 of the ECHR. They guarantee some level of determinacy as to the range

${ }^{12}$ Convention Concerning Forced or Compulsory Labour, 28 June 1930, 39 UNTS 55, Art 2(1).

13 Siliadin [2005] VII Eur Court HR 333, para 123.

14 Ibid.

${ }^{15} \mathrm{CN}$ and Vv France (European Court of Human Rights, Chamber, Application No 67724/09, 11 October 2012) para 91.

${ }^{16}$ Rantsev (2010) 51 EHRR 1, para 282. Interestingly, in Rantsev, the ECtHR also defined human trafficking with reference to the definition of slavery. This approach is problematic and raises questions as to the relationship between the definitions of slavery and human trafficking. For an elaborate discussion of this question, see V Stoyanova, 'Dancing on the Borders of Article 4: Human Trafficking and the European Court of Human Rights in the Rantsev Case' (2012) 30 Netherlands Quarterly of Human Rights 163.

17 Trafficking Convention, Art 4. 
of situations when states are required to act in order to ensure the rights protected under Article 4. They also indicate situations when states are required to use the coercive power of their criminal law by investigating and holding perpetrators of abuses criminally responsible.

\section{Criminalisation as an Aspect of States' Positive Human Rights Obligations under Article 4 of the ECHR}

Originally, the ECHR was conceived as a legal framework defending individuals against state interference. ${ }^{18}$ However, states are not the only perpetrators of abuses. Individuals can be threatened by other individuals who act as private parties and whose actions are not attributable to the state. Migrants in host European countries, in particular, are vulnerable to private harm, including abuses by employers. ${ }^{19}$ In order to address these situations, human rights law has developed additional tools, namely positive obligations. ${ }^{20}$ Criminalising abuses at the domestic level is an aspect of these positive obligations.

Criminalisation is regarded as a means of ensuring the rights protected in the Convention. Pursuant to Article 1 of the ECHR, states are under the obligation not only to respect, but also to secure the rights in the Convention. Thus, Article 1 of the ECHR has been the basis for the development by the ECtHR of positive obligations. ${ }^{21}$ In its case law, the Court has developed different types of positive obligations, including the obligation of adopting effective regulatory frameworks. ${ }^{22}$ Regulatory frameworks are necessary since individuals need to be

${ }^{18}$ See K Starmer, 'Positive Obligations under the Convention', in J Jowell \& J Cooper (eds), Understanding Human Rights Principles (2001) 139.

${ }^{19}$ See generally C Murphy, 'The Enduring Vulnerability of Migrant Domestic Workers in Europe' (2013) 62(3) ICLQ 599; E Albin, 'Introduction: Precarious Work and Human Rights' (2012) 34 Comp Labour L \& Policy J 1; J Fudge 'Precarious Migrant Status and Precarious Employment: the Paradox of International Rights for Migrant Workers' (2012) 34 Comp Labour L \& Policy 95.

${ }^{20}$ Positive human rights obligations are not relevant only in the context of private harm; they are as much of relevance in the context of harm inflicted by agents whose actions are attributable to the state. The present article, however, focuses on private harm.

${ }^{21}$ See A Mowbray, The Development of Positive Obligations under the European Convention on Human Rights by the European Court of Human Rights (2004); C Dröge, Positive Verpflichtungen der Staaten in der Europäischen Menschenrechtskonvention (2003); D Xenos, The Positive Obligations of the State under the European Convention of Human Rights (2011).

22 The ECtHR has elaborated upon, for example, the positive obligation of investigating abuses and the positive obligation of taking protective operational measures. 
provided with legal protection in their relations vis-à-vis the state, its agents and vis-à-vis private actors. The legal protection is effectuated through the adoption of relevant legal rules. ${ }^{23}$ Legal rules are required since it is hard to imagine compliance with the undertaking in Article 1 to secure the Convention rights and freedoms to everyone without some legal basis for all of the latter being provided. ${ }^{24}$ The rights protected in the Convention require 'a positive regulatory environment', which means that states have to adopt legal rules to ensure that individuals can enjoy their rights. ${ }^{25}$ The obligation of criminalising abuses is an aspect of the positive obligation of adopting an effective regulatory framework for ensuring the rights in the ECHR. ${ }^{26}$

The leading cases in which ECtHR elaborated on and affirmed the positive obligation of criminalising abuses are $X v$ The Netherlands ${ }^{27}$ and MC $v$ Bulgaria. ${ }^{28}$ Siliadin $v$ France was the first case in which the obligation of criminalising abuses falling within the material scope of Article 4 of the ECHR was considered. There was a flaw in the French national legislation since there were, inter alia, no specific provisions criminalising slavery, servitude and forced labour. Similar gaps were the object of enquiry in $C N$ and $V v$ France and $C N v$ The United Kingdom. ${ }^{29}$

\footnotetext{
${ }^{23}$ For a comprehensive discussion concerning states' positive obligation of adopting legal frameworks to protect the ECHR's rights, see L Lavrysen, 'Protection by the Law: The Positive Obligation to Develop a Legal Framework to Adequately Protect the ECHR Rights', in E Brems \& Y Haeck (eds), Human Rights and Civil Rights in the $21^{\text {st }}$ Century (2014, in press).

${ }^{24}$ J McBride, 'Protecting Life: A Positive Obligation to Help' [1999] European LR 43, 43.

25 The expression 'positive regulatory environment' was taken from the concurring opinion of Judge Sajó and Judge Tulkens in Ternovszky v Hungary (European Court of Human Rights, Chamber, Application No 67545/09, 14 December 2010).

${ }^{26}$ See generally A Ashworth, Positive Obligations in Criminal Law (2013) 196-211.

${ }^{27} X v$ Netherlands (1985) 91 Eur Court HR, Ser A, para 27. The case of $X v$ Netherlands concerned a mentally handicapped child who was raped in a mental hospital. The case uncovered a gap in the Dutch criminal law. Since neither the child nor her father could file a criminal complaint, there was no possibility for holding the abuser criminally responsible. The ECtHR found a violation of Article 8 of the ECHR since:
}

the protection afforded by the civil law in the case of wrong-doing of the kind inflicted on Miss $\mathrm{Y}$ is insufficient. This is a case where fundamental values and essential aspects of private life are at stake. Effective deterrence is indispensable in this area and it can be achieved only by criminal-law provisions; indeed, it is by such provisions that the matter is normally regulated.

${ }^{28}$ MC v Bulgaria (2005) 40 EHRR 20, para 153. In this case, a girl claimed that she was raped and that the national criminal law failed to provide her with effective legal protection. The ECtHR agreed and found that Bulgaria had violated Article 3 and Article 8 of the ECHR.

${ }^{29} \mathrm{CN}$ and Vv France (European Court of Human Rights, Chamber, Application No 67724/09, 11 
Criminalisation is necessary for ensuring that individuals are protected from abuses inflicted by other individuals. In this sense, the ECtHR regards enactment of criminal law as an instrument for effective deterrence. ${ }^{30}$ It is assumed that the rights under the ECHR cannot be ensured without deterring other individuals from inflicting harms. ${ }^{31}$ To that effect, states have to send a clear message to the abusers that, if detected, they can expect prosecution, conviction and punishment in the normal course of events. ${ }^{32}$

Yet, the argument that criminal law is necessary for better deterrence is susceptible to challenges. More specifically, since the abuse against the individual has already been committed, arguments that the existence of criminal law can deter the specific abuse inflicted on the specific victim are unsustainable. Nothing can be done at this point in time to protect the individual. However, it would be wrong to assume that the positive human rights obligation to criminalise abuses is concerned with specific deterrence. As Jonathan Rogers has explained:

when he [the victim] criticizes the domestic criminal law, he is claiming to be a representative victim of the state's failure to achieve a satisfactory level of general deterrence against the offence in question. It follows, then, that the doctrine of positive obligations is concerned only with general deterrence when it considers whether the state has a duty to adapt its criminal law in response to a particular type of abuse of human rights. ${ }^{33}$

Rogers's explanation is persuasive. However, general deterrence apart, criminalisation also provides specific deterrence against repetition of the conduct by the individual perpetrator and possibly against the individual victim. The latter is particularly relevant in settings involving abuses against migrants. It can be ex-

October 2012) para 105; See also CN v United Kingdom (2013) 56 EHRR 24, para 66.

${ }^{30}$ Branko Tomasic and Others $v$ Croatia (European Court of Human Rights, Chamber, Application No 46598/06, 15 January 2009) para 49; Opuz v Turkey [2009] III Eur Court HR 107, para 128; See P Londono, 'Developing Human Rights Principles in Cases of Gender-based Violence: Opuz $v$ Turkey in the European Court of Human Rights' (2009) 9 Human Rights LR 657.

31 The question of the actual deterrent effect of the criminal law has never been profoundly discussed by the ECtHR. In the ECtHR's judgments, it is simply assumed that the establishment of criminal offences can act as deterrence.

32 J Rogers, 'Applying the Doctrine of Positive Obligations in the European Convention on Human Rights to Domestic Substantive Criminal Law in Domestic Proceedings' [2003] Crim LR 690, 695.

33 Ibid. 
pected that an abuser who has been subjected to criminal prosecution, convicted and/or punished will be deterred from engaging in abusive practices again.

It can also be discerned from the ECtHR's case law that criminalisation is viewed as having important value for the individual victim. Criminal law makes it possible for the victim to see the abusers convicted and sentenced. For example, in Siliadin, the Court observed that '[...] in the instant case, the applicant who was subjected to treatment contrary to Article 4 and held in servitude, was not able to see those responsible for the wrongdoing convicted under the criminal law. ${ }^{34}$

\section{The Relation between Positive Human Rights Obligations and National Criminal Law}

As the previous section demonstrated, human rights law can shape the national criminal law by requiring it to criminalise the abuses falling within the scope of Article 4. Herein, I undertake a more general enquiry of the relationship between national criminal law and international human rights law. ${ }^{35}$ These two bodies of law are different in terms of their purposes, objects of regulation and interpretation techniques. These differences have an impact as to how slavery, servitude, forced labour and THB are to be defined and how their respective definitions are to be interpreted in the context of criminal law and in the context of human rights law. The differences have largely remained ignored in the existing literature on slavery, servitude, forced labour and THB.

Jean Allain has made a major contribution to the better understanding of the meaning of slavery, servitude and forced labour. He argued that slavery as defined in the 1926 Slavery Convention should be understood as 'control over a person in such a way as to significantly deprive that person of his or her individual liberty, with the intent of exploitation through the use, management, profit, transfer or

\footnotetext{
${ }^{34}$ Yet, the Court has emphasised that the ECHR does not guarantee a right of the victim of a crime to have someone prosecuted and punished. See Öneryildiz v Turkey [2009] XII Eur Court HR 79, para 96; See also A Seibert-Fohr, Prosecuting Serious Human Rights Violations (2009) 119; J McBride, Human Rights and Criminal Procedure: The Case Law of the European Court of Human Rights (2009) 276.

35 This relationship has been predominantly investigated from the perspective of the human rights of accused and/or convicted persons. See A Ashwoth \& B Emmerson, Human Rights and Criminal Justice (2001); A Ashwoth, 'Criminal Law, Human Rights and Preventive Justice', in B McSherry, A Norrie \& S Bronitt (eds), Regulating Deviance: The Redirection of criminalisation and the Futures of Criminal Law (2009).
} 
disposal of that person. ${ }^{36}$ His analysis seems to be situated within the context of criminal law since he seeks to identify concrete actions which a perpetrator undertakes to keep a person in slavery. ${ }^{37}$ At the same time, Allain criticises scholars and UN bodies for construing the concept of slavery in an expansive way which is not in conformity with the 1926 slavery definition. While in principle his criticisms are well substantiated, ${ }^{38}$ he is not sufficiently attentive to the tension which exists between, on the one hand, the criminal law approach requiring precise definitions and determinacy of the elements of crimes and, on the other hand, the human rights law approach, guided by the rationale of expanding the beneficiaries of protection and of more involvement by the state in protection.

As a result of the above mentioned insensitivity, the contexts of individual criminal responsibility and state responsibility under international human rights law seem to be blurred. For example, Allain has submitted that the 1926 slavery definition 'is wide enough to be accepted by advocates, but also opens a new vista, one which can be used to hold states and individuals responsible for enslavement, whether de jure or de facto. ${ }^{39}$ Holding individuals criminally responsible for slavery needs to be conceptually separated from holding states internationally responsible for enslavement. In addition, within the Council of Europe and even within broader geographical lines, it is not likely that states enslave individuals; rather, states might be found in breach of their positive human rights obligations for failing to protect persons who are subjected to abuses by private parties.

The literature on THB has been fundamentally oblivious of the basic principles underlying national criminal law. Anne Gallagher offers an analysis of the THB definition which disregards the purpose for which the definition is inter-

\footnotetext{
${ }^{36}$ Bellagio-Harvard Guidelines on the Legal Parameters of Slavery, <http://www.law.qub.ac.uk/schools/SchoolofLaw/FileStore/Filetoupload,398946,en.pdf> [accessed 19 March 2014]. See also J Allain, Slavery in International Law: Of Human Exploitation and Trafficking (2013) 128; R Hickey, 'Seeking to Understand the Definition of Slavery', in J Allain (ed), The Legal Understanding of Slavery. From the Historical to the Contemporary (2012) 220.

${ }^{37}$ Allain and Hickey also state that the 1926 definition provides a powerful way forward for identifying and prosecuting cases of slavery'. J Allain \& R Hickey, 'Property and the Definition of Slavery' (2012) 61 ICLQ 915, 924.

${ }^{38}$ As Suzanne Miers has remarked, slavery has been used as a referent to various social problems and injustices which can ultimately render the concept meaningless. See S Miers, Slavery in the Twentieth Century (2003) 453. An example to this effect is the UN High Commissioner for Human Rights' Report entitled Abolishing Slavery and its Contemporary Forms, authored by D Weissbrodt and Anti-Slavery International, UN Doc HR/PUB/02/4. The report includes under the rubric of 'forms of slavery' various practices, including prostitution, without offering meaningful legal analysis of the legal parameters of the concept of slavery.

${ }^{39}$ J Allain, 'The Definition of Slavery in International Law' (2009) 52 Howard LJ 239, 242.
} 
preted: for the purpose of its incorporation in the national criminal law or for the purpose of delineating a group of individuals, victims of human trafficking, who are eligible for certain protection measures. ${ }^{40}$ She has submitted that the THB definition is 'inclusive', covering 'a wide range of contemporary exploitative practices', and that 'it is difficult to identify a "contemporary form of slavery" that would not fall within its generous parameters. ${ }^{41}$ Therefore, Gallagher is a proponent of interpreting THB broadly. However, she does not ask herself the question whether this is acceptable from the perspective of the application of national criminal law and the rights of the accused. A similar approach has been adopted by Venla Roth. Roth's analysis appears to be contextualised in the field of criminal law. Yet, without acknowledging the constraints of the criminal law context, she has submitted that it is necessary to understand the definition [of THB] in a way which allows broader interpretations. ${ }^{42}$

Ryszard Piotrowicz and Alice Edwards have drawn attention to the two separate fields of law, namely international human rights law and national criminal law, which are of relevance in the context of abuses against migrants. ${ }^{43}$ Piotrowicz, has rightly pointed out that THB is usually a private criminal act and that further explanations solidly grounded in the rules for finding states' internationally responsible under human rights law are necessary for conceptualising THB as a human rights issue. ${ }^{44}$ However, Piotrowicz and Edwards have not investigated the definitional implications: how abuses are defined and interpreted in the context of national criminal law and in the context of international human rights law.

In light of the above outlined deficiencies, it is necessary to shed some light on the interactions between human rights law and criminal law and on the differences between these fields of law in terms of purposes, objects of regulation and interpretation techniques. Human rights law is meant to bind states, while criminal law is enforced with regard to individuals at a national

\footnotetext{
${ }^{40}$ A Gallagher, The International Law of Human Trafficking (2010) 12-53.

${ }^{41}$ A Gallagher, 'Human Rights and Human Trafficking: Quagmire or Firm Ground? A Response to James Hathaway' (2009) 49(4) Va J Int L 789, 811-14.

${ }^{42} \mathrm{~V}$ Roth, Defining Human Trafficking and Identifying Its Victims: A Study on the Impact and Future Challenges of International, European and Finnish Legal Responses to Prostitution-related Trafficking in Human Beings (2012) 75.

${ }^{43}$ R Piotrowicz, 'The Legal nature of Trafficking in Human Beings' (2009) 4 Intercultural Human Rights LR 175; A Edwards, 'Traffic in Human Beings: At the Intersection of Criminal Justice, Human Rights, Asylum/Migration and Labour' (2007) 36 Denver JILP 9.

${ }^{44}$ R Piotrowicz, 'States' Obligations under Human Rights Law towards Victims of Trafficking in Human Beings: Positive Developments in Positive Obligations' (2012) 24(2) Int J Refugee L 181.
} 
level. Since these two bodies of law have different purposes, the transplantation of concepts and case law from human rights law to criminal law and vice versa should not be endorsed uncritically. Since human rights law applies to the state, it seeks to improve practices by states in order to advance the protection of beneficiaries. Criminal law focuses on the culpability of individuals. The purpose of criminal law is to hold individuals criminally responsible. The purpose of human rights law is to maximise protection for individuals, including those who might suffer abuses by private parties. Certainly, national criminal law also aims at protecting society. In addition, many of its prohibitions are rooted in human rights law and are intended to reinforce those rules. However, as Darryl Robinson noted, the 'general justifying aim' of the criminal law system as a whole-which may be a utilitarian aim of protecting society-cannot be conflated with the question of whether it is justified to punish a particular individual for a particular crime. ${ }^{45}$ Liora Lazarus also warned that the duty of general protection against the population at large cannot be deployed to justify the coercion of a particular individual in a particular way. ${ }^{46}$

Human rights law and criminal law have different objects of regulation. Human rights law focuses on systems. It seeks to improve practices of states in order to advance protection of individuals. Criminal law can reinforce this objective. However, it focuses on individual criminal responsibility and is restrained by certain principles such as the principles of personal culpability and fair warning. ${ }^{47}$ The principle of personal culpability means that persons are held responsible only for their own conduct. This principle also requires knowledge and intent in relation to the conduct so that the person can be found responsible. The principle of fair warning relates to the principle of legality, which requires that definitions of crimes be construed strictly in order to provide fair notice to individual actors and to constrain arbitrary exercise of states' coercive power. ${ }^{48}$

In the field of criminal law the behaviour which is to be considered a criminal offence must be precisely defined. In case it is not, this might come into clash with the defendant's human rights. ${ }^{49}$ The requirement for a clear definition

\footnotetext{
${ }^{45}$ D Robinson, 'The Identity Crises of International Criminal Law' (2008) 21 Leiden JIL 925, 938.

${ }^{46}$ L Lazarus, 'Positive Obligations and Criminal Justice: Duties to Protect or Coerce', in L Zadner \& J Roberts (eds), Principles and Values in Criminal Law and Criminal Justice: Essays in Honour of Andrew Ashworth (2012) 136, 150.

${ }^{47}$ Robinson, above $\mathrm{n} 45,946-7$.

${ }^{48}$ See P Robinson, 'Fair Notice and Fair Adjudication: Two Kinds of Legality' (2005) 154 Un Pa LR 335. See generally K Gallant, The Principle of Legality in International and Comparative Criminal Law (2009).

${ }^{49}$ See Article 7 of the ECHR; see also Sunday Times v United Kingdom (1979) 30 Eur Court HR, Ser
} 
of the offence is satisfied 'where the individual can know from the wording of the relevant provision-and, if need be, with the assistance of the courts' interpretation of it and with informed legal advice-what acts and omissions will make him criminally liable. ${ }^{50}$ In addition, crimes cannot be extensively interpreted or interpreted by analogy. ${ }^{51}$

It should be, however, also kept in mind that progressive development of criminal law is not precluded:

$[\mathrm{h}]$ owever clearly drafted a legal provision may be, in any system of law, including criminal law, there is an inevitable element of judicial interpretation. There will always be a need for elucidation of doubtful points and for adaptation to changing circumstances. Indeed, in the Convention States, the progressive development of the criminal law through judicial law-making is a well-entrenched and necessary part of legal tradition. Article 7 of the Convention cannot be read as outlawing the gradual clarification of the rules of criminal liability through judicial interpretation from case to case, provided that the resultant development is consistent with the essence of the offence and could reasonably be foreseen. ${ }^{52}$

Therefore, there is no absolute adherence to the principle of legality. ${ }^{53}$ Some crimes are vague and this is inevitable for avoiding 'excessive rigidity and to keep pace with changing circumstances. ${ }^{54}$ Yet, the principle of legality has a central role.

In the realm of human rights, the requirement of a definition means that the material scope of Article 4 must be delimited so that there is clarity as to the conduct from which the state has to restrain itself. From the perspective of states' positive human rights obligations, the purpose of the definitions of slavery, servitude and forced labour is to demarcate the range

\footnotetext{
A.

${ }^{50}$ Korbely v Hungary [2008] IV Eur Court HR 299, para 70 (Korbely).

${ }^{51}$ ES $v$ Sweden (European Court of Human Rights, Chamber, Application No 5786/08, 21 June 2012) para 69. For elucidation of the general principles which the ECtHR applies in relation to nullum crime, nulla poena sine lege, see Kasymakhunov v Russia (European Court of Human Rights, Chamber, Application Nos 26261/05 \& 26377/06, 14 March 2013) paras 76-8.

${ }^{52}$ Korbely [2008] IV Eur Court HR 299, para 71.

${ }^{53}$ M Shahabuddeen, 'Does the Principle of Legality Stand in the Way of Progressive Development of Law?' (2004) 2 JICJ1007.

${ }^{54}$ Kokkinaksi v Greece (1993) 260-A Eur Court HR, Ser A, para 40.
} 
of circumstances in which the state has an obligation to act. Importantly, human rights norms, including Article 4 of the ECHR, are in principle framed vaguely and in broad terms. ${ }^{55}$ Human rights norms have to be subjected to interpretation. The interpretation techniques endorsed by the ECtHR favour progressive and expansive interpretation. ${ }^{56}$ These techniques of interpretation are not appropriate in the context of criminal law.

Therefore, human rights law and criminal law rest on two contradictory interpretative approaches. Criminal law principles forbid an expansive interpretation of norms, while human rights law celebrates such expansions. Since criminal law must remain faithful to the principle of legality, interpretative approaches to human rights law which favour a liberal construction for the purpose of maximising protection for beneficiaries are contrary to the principles underpinning the criminal justice system. ${ }^{57}$

The concrete abuses of human trafficking and of subjecting someone to forced labour can be used to demonstrate the above points. The person who commits recruitment by means of deception has to have the specific mens rea in order to be found guilty of human trafficking. He/she should be aware that he/she is recruiting and that he/she recruits for the purpose of exploitation. The application of criminal law requires that the mens rea of the alleged trafficker be proven beyond reasonable doubt. An employer who threatens his/her employee with a penalty could be found guilty of subjecting that employee to forced labour. The application of criminal law requires an examination of the specific actions of the specific employer who allegedly subjected his/her employee to forced labour.

From the perspective of human rights law, when asking the question whether the state has failed to ensure that migrants not be subjected to Article 4's abuses, the mens rea of the alleged trafficker and abusive employer is irrelevant. ${ }^{58}$ Instead, we are interested in the overall situation of the victim and the abuses which he/she has suffered irrespective of who inflicted those abuses and what intention each specific perpetrator had. ${ }^{59}$ In human rights law, the specific

${ }^{55}$ S Trechsel, 'Comparative Observations on Human Rights Law and Criminal Law' (2000) St Louis-Warsaw Transnational LJ 1, 17.

${ }^{56}$ ECtHR has determined that the ECHR is intended to guarantee rights that are practical and effective' and that the Convention is 'a living instrument'. See Tyrer v United Kingdom (1978) 26 Eur Court HR, Ser A.

${ }^{57}$ Robinson, above n 45, 929.

${ }^{58}$ A Nollkaemper, 'Concurrence between Individual Responsibility and State Responsibility in International Law' (2003) 52 ICLQ 615, 617.

${ }^{59}$ Human rights law can only be interested in the question of who inflicted the abuses if the perpetrator is a state's agent and/or when his/her actions are attributed to the state. However, 
actions by the employer who allegedly subjected the victim to forced labour could be of relevance. However, in the context of human rights law the broader circumstances of the victim's situation have to be inspected. The focus is on the overall conditions surrounding the victim and whether these conditions amount to abuses falling within the scope of Article 4.

In addition, for the purposes of applying some of the positive human rights obligations as developed by the ECtHR, it is not even necessary to demonstrate that the migrant's circumstances necessarily qualify as slavery, servitude, forced labour or THB. States may be found responsible for their failure to conduct effective investigation into alleged abuses when migrants' complaints give rise to a reasonable suspicion that they have been held in conditions of, for example, servitude. In $C N v$ United Kingdom, a judgment in which the ECtHR found that the respondent government failed to investigate a potential situation of servitude, the question whether the applicant was indeed held in servitude was not considered. ${ }^{60}$ The Court noted that her complaints concerning the abuses could not be assessed as 'inherently implausible' and concluded that these complaints 'did give rise to a credible suspicion that she had been held in conditions of domestic servitude, which in turn placed the domestic authorities under an obligation to investigate those complaints. ${ }^{61}$

Similarly, it should be underscored that when the Court applies the positive obligation of taking protective operational measures, the criteria triggering this obligation do not necessarily include demonstrating that the migrant was held in slavery, servitude or forced labour. As these criteria have been originally expanded in Osman $v$ United Kingdom and applied since then, ${ }^{62}$ it must be established that 'the authorities knew or ought to have known at the time of the existence of a real and immediate risk' that a person could be subjected to the criminal acts by another individual. ${ }^{63}$ Accordingly, at the time when the events were unfolding, state authorities need not necessarily be convinced that the migrant was kept in slavery, servitude or forced labour. Notably, the criminal

this scenario is excluded from the present analysis.

${ }^{60} \mathrm{CN} v$ United Kingdom (2013) 56 EHRR 24, paras 69, 71, 72.

${ }^{61}$ Ibid, paras 72-3. The Court did not refer to the established phraseology of 'reasonable suspicion'. Instead, it used the expression 'credible suspicion'. I find this change very problematic. However, it goes beyond the purposes of the present article to elaborate upon this issue.

${ }^{62}$ Osman v United Kingdom [1998] VIII Eur Court HR 3124, para 116; see also Opuz v Turkey [2009] III Eur Court HR 107.

${ }^{63}$ See also Rantsev (2010) 51 EHRR 1, para 286. In Rantsev, the ECtHR modifies the wording of the Osman test without offering any explanations. Discussing the implications of this modification, however, goes beyond the scope of this article. 
culpability of any alleged perpetrators and their mens rea are immaterial.

In human rights law, the focus is on the state and its system of protection. In the context of positive human rights obligations, the focus is on identifying failures by the state. This reflects its origins as a subset of the general international law of state responsibility. ${ }^{64}$ Broader meaning of norms means more protection for individuals by the state. Since the addressee of human rights norms is the state, the underlying assumption is that progressive and broader interpretation of norms is the better articulation. This is not the case in the context of criminal law. Human rights interpretative techniques can conflict with the principles underlying the contemporary criminal justice systems.

Therefore, the transition from criminal law to human rights law, which is about responsibility of a collective (the state), requires a conceptual move. In light of this, it could be submitted that different questions are asked in the context of criminal law for the purpose of finding a suspect guilty and in the context of human rights law for the purpose of finding the state responsible for its failures. It can also be submitted that under human rights law, more flexibility as to the meaning of slavery, servitude, forced labour and THB can be expected. It could be advanced that this flexibility is desirable since this might expand the range of circumstances in which states' obligations are triggered and widen the scope of protected persons.

At this junction, however, the interests of the states should not be ignored. There is a clear need for determinacy in the context of human rights law also. Otherwise, the human rights law concepts of slavery, servitude, forced labour and THB will be rendered ineffective and there will be no clarity as to the human rights obligations held by states. Therefore, the interpretative techniques applicable to human rights law also have limitations. Furthermore, despite the tolerated definitional flexibility in the realm of human rights, the ECtHR has strived to delineate the material scope of the rights protected in the ECHR and to elaborate upon their meanings. Therefore, the expectation of definitional flexibility should not be interpreted to the effect that the terms covered by Article 4 are at risk of being subjected to conceptual disintegration.

An additional caveat must also be mentioned. The above text might seem to imply that the interpretation techniques applied in human rights law work only in favour of the alleged victims of crimes or the alleged victims of human rights violations. This is a deceptive impression. An expansive interpretation of

\footnotetext{
${ }^{64}$ A M Danner \& J Martinez, 'Guilty Associations: Joint Criminal Enterprise, Command Responsibility and the Development of International Criminal Law' (2005) 93 Ca LR 75, 87.
} 
human rights norms works equally for the protection of the alleged perpetrators of crimes. Human rights law applies to criminals as well. For example, a person might complain that he has been convicted for a crime contrary to the principle of nullum crimen sine lege, which embodies the requirement for clarity of the definitions of crimes.

My efforts to draw the lines demarcating the distinctions between criminal law and human rights law should not be misunderstood to the effect that there is no interaction between the two levels. The mere positive obligation upon states to criminalise certain forms of abuses is an expression of the interaction. The interaction also extends further. When there is a deficit in terms of interpretative guidelines, criminal law can benefit from developments in the realm of human rights law and vice-versa. In addition, human rights law can set standards regarding how national crimes should be defined and interpreted so that they can be effectively applied for the purposes of investigation, prosecution and conviction. These issues and their relevance to Article 4 of the ECHR are an object of enquiry in the two forthcoming sections.

\section{Criminalisation under the Specific Labels of Slavery, Servitude and Forced Labour}

The questions addressed in this section are whether state parties to the ECHR are under an obligation to adopt the specific criminal law labels of slavery, servitude and forced labour in their domestic law, and how the existence of these specific criminal law labels affects the interpretation of abuses against migrants. I argue that against the backdrop of the lack of criminalisation at the national level of slavery, servitude and forced labour, the abuses against migrants are conceptualised with reference to the crime of human trafficking. This could create gaps in the national criminal law as a result of which abuses against migrants might not be properly addressed.

Siliadin, $C N$ and $V v$ France and $C N v$ United Kingdom will be used as a basis for responding to the above questions. As already mentioned, the primary importance of Siliadin lies in the recognition that states have to criminalise at the domestic level abuses falling within the material scope of Article $4{ }^{65}$ Critically, however, the French criminal law contained criminal offences which

${ }^{65} \mathrm{H}$ Cullen, 'Siliadin v France: Positive Obligations under Article 4 of the European Convention on Human Rights' (2006) 6 HRLR 585; A Nicholson, 'Reflection on Siliadin v France: Slavery and Legal Definition' (2010) 14 IJHR 705. 
could have been operationalised for holding the family which used Siliadin's services criminally responsible. In particular, it was a criminal offence:

to obtain from an individual the performance of services without payment or in exchange for payment that is manifestly disproportionate to the amount of work carried out, by taking advantage of that person's vulnerability or state of dependence. ${ }^{66}$

Pursuant to French criminal law, it was also a criminal offence 'to subject an individual to working or living conditions which are incompatible with human dignity by taking advantage of that individual's vulnerability or state of dependence'.67 In relation to these criminal law provisions, the ECtHR observed that 'these provisions do not deal specifically with the rights guaranteed under Article 4 of the Convention, but concern, in a much more restrictive way, exploitation through labour and subjection to working and living conditions that are incompatible with human dignity' ${ }^{68}$

The abuses of subjecting someone to forced labour, to servitude or to slavery were not as such defined as crimes at the national level. Instead, there were other criminal offences, i.e., the ones quoted above. The existing criminal law offences were more restrictive regarding the scope of abuses covered because they required the findings of taking advantage of a person's vulnerability or state of dependence and incompatibility with human dignity. ${ }^{69}$ Not only was there a tendency by the national courts to interpret them restrictively, but due to their ambiguity there was also a lack of consistency regarding how to interpret them at all. The same deficiencies were found to be at the core of the violation in $C N$ and $V v$ France.

Yet, the Court's reasoning in Siliadin and $C N$ and $V v$ France is not that straightforward. These judgments could be also interpreted to the effect that the failure of the respondent state lay not so much in the lack of criminalisation of specifically slavery, servitude and forced labour, but rather in the ambiguity of the existing crimes at the national level and their restrictive interpretation by

\footnotetext{
${ }^{66}$ Criminal Code (France), Art 225-13.

${ }^{67} \mathrm{Ibid}$, Art 225-14.

${ }^{68}$ Siliadin [2005] VII Eur Court HR 333, para 142.

${ }^{69} \mathrm{Ibid}$, para 141. Other authors have argued that the lack of a specific offence of servitude did not in itself violate Article 4 of the ECHR. See B Rudolf \& A Eriksson, 'Women's Rights under International Human Rights Treaties: Issues of Rape, Domestic Slavery, Abortion, and Domestic Violence' (2007) 5(3) Int J Const L 507, 516.
} 
the national courts. ${ }^{70}$ In this sense, if the existing national crimes-although not labelled as slavery, servitude or forced labour-were interpreted more broadly and in a consistent manner by the national courts, the respondent state would not be in violation of Article 4 .

A reference to $C N v$ United Kingdom can further enrich the discussion. The applicant submitted that since the UK had not enacted domestic law specifically criminalising the conduct prohibited by Article 4, 'any investigation into her complaints was ineffective as it was not directed at determining whether or not she had been a victim of treatment contrary to Article 4 and could not therefore result in a prosecution. ${ }^{71}$ In response, the UK submitted that:

Article 4 did not require that the effective protection against the prohibited conduct should be achieved by means of the adoption of a single, specific criminal offence. At the time of the conduct alleged by the applicant there were a number of offences in English law which criminalised the essential aspects of slavery, servitude and forced or compulsory labour. ${ }^{72}$

The UK referred to the following offences: human trafficking, kidnapping, grievous bodily harm, assault, blackmail, harassment and employment-related offences. The ECtHR responded that:

In view of the Court's finding in Siliadin, it cannot but find that the legislative provisions in force in the United Kingdom at the relevant time were inadequate to afford practical and effective protection against treatment falling within the scope of Article 4 of the Convention. Instead of enabling the authorities to investigate and penalize such treatment, the authorities were limited to investigating and penalizing criminal offences which often-but do not necessarily-accompany the offences of slavery, servitude and forced labour. Victims of such treatment who were not also victim of one of these related offences were left without any remedy. ${ }^{73}$

\footnotetext{
70 The elements of 'taking advantage of a person's vulnerability' and 'incompatibility with human dignity' were subjected to various interpretations by the French courts.

${ }^{71}$ CN v United Kingdom (2013) 56 EHRR 24, para 47.

${ }^{72}$ Ibid, para 56.

${ }^{73}$ Ibid, para 76 (emphasis added).
} 
The ECtHR emphasised that domestic servitude is a specific offence. It found that due to the absence of the specific offence of domestic servitude, the domestic authorities were unable to give due weight to various factors regarding the applicant's situation, such as overt and subtle forms of coercion. ${ }^{74}$

In sum, the ECtHR has not categorically said that states must adopt the specific labels of slavery, servitude and forced labour in their domestic law. Yet, for the following reasons I submit that implicitly there is such a requirement. ${ }^{75}$ What emerges from $C N v$ United Kingdom is that the issue of interpretation is consecutive. In this sense the labels of slavery, servitude and forced labour are needed before one can discuss how they should be interpreted. Article 4 is not neutral regarding the assessment made at the national level of the different possible legal bases for prosecution. The specific criminal labels of slavery, servitude and forced labour are necessary because they have an impact on the way in which abuses against migrants are interpreted. Only once having specific criminalisation of slavery, servitude and forced labour can issues of interpretation be addressed and proper regard be taken of the interpretative developments in human rights law. If the labels are not present at the national level, the international law developments in terms of acceptance of subtle forms of coercion against migrants might be disregarded. In this respect, the ECtHR observed that domestic servitude is an offence which:

involves a complex set of dynamics, involving both overt and more subtle forms of coercion, to force compliance. A thorough investigation into complaints of such conduct therefore requires an understanding of the many subtle ways an individual can fall under the control of another. [...] no apparent weight was attributed to the applicant's allegations that her passport had been taken from her, that P.S. had not kept her wages for her as agreed, and that she was explicitly and implicitly threatened with denunciation to the immigration authorities [...]. ${ }^{76}$

Therefore, states' obligations under Article 4 of the ECHR shape the national criminal law. If interpretative developments in the field of human rights law are

\footnotetext{
${ }^{74}$ Ibid, para 80.

${ }^{75}$ For a different perspective on this very issue, see M Eriksson, 'The Prevention of Human Trafficking: Regulating Domestic Criminal Legislation through the European Convention on Human Rights' (2013) 82 Nordic JIL 339, 352.

${ }^{76} \mathrm{CN} v$ United Kingdom (2013) 56 EHRR 24, para 80.
} 
disregarded, the national criminal law could be found incomplete, leading to the lack of criminal investigations. This way the discretion left for the States as to how to label abuses and how to interpret the elements of crimes can in effect be restrained.

In addition to the ECtHR's judgments, further arguments can be advanced in support of the proposition that states need to incorporate the specific criminal law labels of slavery, servitude and forced labour. ${ }^{77}$ First, applying other labels might diminish the gravity of the abuses. ${ }^{78}$ Second, the essence of the wrongdoing might not be captured by other criminal law labels. The essence and the gravity of the abuses could not be represented if they were labelled as ordinary coercion by instance, when in fact the abuses amount to servitude. Third, specific criminalisation ensures strengthening of the deterrent effect and enables the tracking and monitoring of the specific crime. At this juncture, the reader should be reminded that deterrence is the main justification proposed by the ECtHR for criminalising the abuses falling within the scope of Article 4. Therefore, if indeed deterrence is what is sought to be achieved, then having the specific labels is necessary.

Finally, the principle of 'fair labelling' also plays a role. The principle relates to the questions of how the content of the national criminal law should be structured, how one should distinguish wrongs from each other and how the content of the wrongs should be articulated. ${ }^{79}$ The principle of 'fair labelling' requires that 'the label of the offence should fairly express and signal the

\footnotetext{
${ }^{77}$ These arguments have been explored in the context of international criminal law. International criminal law faces the issue whether international crimes need to be incriminated in domestic law in specific terms. The question under discussion is whether states need to have specific provisions in their domestic legislation for crimes against humanity or whether they are allowed to use 'common' crimes such as murder to effectively prosecute the offenders. See C Kress \& F Lattanzi (eds), The Rome Statute and Domestic Legal Orders, vol 1 (2000), vol 2 (2006); O Bekou, 'Crimes at Crossroads: Incorporating International Crimes at the National Level' (2012) 10 JICJ 677, 691.

${ }^{78}$ A similar argument has been submitted in relation to the question whether states need to have a specific crime of torture under their domestic law in light of their obligations under the Convention Against Torture. The Committee Against Torture recommended the introduction of a separate offence to torture. The Committee underscored the close relationship between Arts 4(1) and 4(2) of the Convention Against Torture, suggesting that the absence of a separate offence of torture in the national legal order is likely to result in penalties which do not take the grave nature of torture adequately into account. See A Marchesi, 'Implementing the UN Convention Definition of Torture in National Criminal Law' (2008) 6 JICJ 195, 214.

${ }^{79}$ V Tadros, 'Fair Labeling and Social Solidarity', in L Zedner \& J Roberst (eds), Principles and Values in Criminal Law and Criminal Justice: Essays in Honour of Andrew Ashworth (2012) 68, 69.
} 
wrongdoing of the accused, so that the stigma of conviction corresponds to the wrongfulness of the act. ${ }^{80}$ Labelling reflects the moral judgments that the public makes about the relevant conduct. ${ }^{81}$ Therefore if migrants are subjected to abuses which in terms of content and level of gravity amount to slavery, servitude and forced labour, these abuses should be labelled as such in compliance with the principle of 'fair labelling'.

Against the backdrop of the above, the issue of whether the Council of Europe member states have actually lived up to their obligation to criminalise the abuses of slavery, servitude and forced labour needs to be reviewed. As a result of their obligations under the Council of Europe Trafficking Convention, states have incorporated the crime of THB in their domestic criminal legislation. ${ }^{82}$ However, states have largely ignored the need for criminalising slavery, servitude and forced labour. The ILO has reported that the vast majority of the ILO member States have not provided for the specific offence of forced labour in their criminal law. ${ }^{83}$ My review of the national criminal legislation, which was greatly facilitated by the GRETA reports from the first evaluation round, demonstrates that, besides the United Kingdom, no other country has a specific criminal offence of forced labour and servitude. ${ }^{84}$ For example, it has been reported that pursuant to Dutch criminal law, it is impossible to prosecute forced labour in cases where trafficking is not present. ${ }^{85}$ Similarly, in Ireland, forced labour is dealt with under the anti-trafficking law and is not a separate offence. ${ }^{86}$ In Bulgaria, the abuses of

${ }^{80}$ Robinson, above n 45, 927.

${ }^{81}$ A Ashworth, Principles of Criminal Law (2009), 78-80.

${ }^{82}$ See GRETA's reports, <http://www.coe.int/t/dghl/monitoring/trafficking/Docs/Evaluation_Reports/default_en.asp $>$ [accessed 19 March 2014].

${ }^{83}$ A Global Alliance Against Forced Labour, Global Report under the Follow-up to the ILO Declaration on Fundamental Principles and Rights at Work 2005, UN Doc ILC.93/I(B), 16 June 2005, 7.

${ }^{84}$ In some jurisdictions, forced labour is criminalised as a war crime and/or as a crime against humanity. See e.g. Criminal Code (Bosnia and Herzegovina), Art 173; Criminal Code (Latvia), Art 74; Criminal Code (Malta), Arts 54(C)(1), 54(D)(b). In France, reduction to slavery could be a crime against humanity if other conditions are also present. See J Verner, 'French Criminal and Administrative Law Concerning Smuggling of Migrants and Trafficking in Human Beings: Punishing Trafficked Persons for their Protection?', in E Guild \& P Minderhoud (eds), Immigration and Criminal Law in the European Union: The Legal Measures and Social Consequences of Criminal Law in Member States on Trafficking and Smuggling in Human Beings (2006) 7, 22-3.

${ }^{85} \mathrm{M}$ Houwerzijl \& C Rijken, Responses to Forced Labour in the EU: Country Report of The Netherlands, 2, <http://workinglives.org/fms/MRSite/Research/wlri/Netherlands\%20Responses\%20to\%20Forced\%20Labour\%20\%20in\%20the\%20EU.pdf> [accessed 19 March 2014].

${ }^{86}$ Migrant Rights Centre Ireland, Forced Labour: The Case for Criminalisation, 2010, <http://mrci.ie/wp-content/uploads/2012/11/Forced-Labour_The-Case-forCriminalisation.pdf $>$ [accessed 19 March 2014]. For an elaborate discussion on the Irish 
slavery, servitude and forced labour are not criminalised outside the context of human trafficking. ${ }^{87} \mathrm{~A}$ few states have specifically criminalised slavery. ${ }^{88}$

Pursuant to the national criminal laws, abuses against migrants are primarily conceptualised with reference to the migration process under the concept of human trafficking. As required by the crime of human trafficking, abuses are to be interpreted with reference to the deception/coercion in relation to, inter alia, the recruitment, transfer, receipt of the person. As demonstrated by the ECtHR's cases of $\mathrm{CN} v$ United Kingdom and Kawogo $v$ United Kingdom, abusers do not necessarily participate in, inter alia, recruitment, transfer, receipt. ${ }^{89}$ Neither do abusers necessarily recruit, transfer, receipt, inter alia, migrants by means of deception/coercion. In $C N v$ United Kingdom, the ECtHR observed that the investigating authorities had heavily focused on the offence of THB, while ignoring the abuse of domestic servitude. ${ }^{90}$ Similarly, in Kawogo v United Kingdom, the applicant's abusers did not arrange or facilitate her arrival in the United Kingdom for the purposes of exploitation. ${ }^{91}$ As a result, they were not

legislation, see D Keane, 'Abolitionist in Heart But Not in Action: Slavery, Servitude and the Status of Article 4 in Irish Law' (2013) 50 Irish Jurist 166.

${ }^{87}$ V Stoyanova, 'The Crisis of a Definition: Human Trafficking in Bulgarian Law' (2013) 5 Amsterdam L Forum 64.

${ }^{88}$ There has been a misperception that 'virtually all States have domestic norms which deal with slavery as a crime'. See F Lenzerini, 'Suppressing Slavery under Customary International Law' (2000) 10 Italian YIL 145, 155. Within the Council of Europe, examples of states which have specific criminal provisions on slavery are Norway (Criminal Code [Norway], Art 225), Italy (Criminal Code [Italy], Art 600), Austria (Criminal Code [Austria], Art 104), Bosnia and Herzegovina (Criminal Code [Bosnia and Herzegovina], Art 185), Croatia (Criminal Code [Croatia], Art 175), the United Kingdom (Coroners and Justice Act 2009 [UK] s 71) and Portugal (Criminal Code [Portugal], Art 159).

${ }^{89}$ In the United Kingdom, slavery, servitude and forced labour were criminalised only in 2009 with the Coroners and Justice Act. In contrast, human trafficking in prostitution was criminalised with section 145, The Nationality, Immigration and Asylum Act 2002 (The Sexual Offences Act 2003 repealed this provision and replaced it with the offence of trafficking or sexual exploitation). The Asylum and Immigration (Treatment of Claimants, etc.) Act 2004 created the offence of trafficking people for exploitation. See I MacDonald \& R Toal, MacDonald's Immigration Law and Practice (2010) 1232-3. See also the Protection of Freedoms Act 2012, which introduced amendments to the Sexual Offences Act 2003 and the Asylum and Immigration Act (Treatment of Claimants, etc.) 2004.

${ }^{90} \mathrm{CN} v$ United Kingdom (2013) 56 EHRR 24, para 80.

${ }^{91}$ Kawogo v United Kingdom (European Court of Human Rights, Chamber, Application No 56921/09, 3 September 2013). In light of the declaration submitted by the respondent government the ECtHR decided to strike the application out. The reasons for not continuing with the examination of the application were, inter alia, that with the adoption of Section 71 of the Coroners and Justice Act 2009 the specific offences of slavery, servitude and forced labour 
subjected to prosecution since the elements of the crime of human trafficking were not constituted. The mere fact that the family which used Elisabeth Kawogo's services subjected her to abuses, which could qualify as slavery, servitude or forced labour, was not sufficient to meet the element of the offence of human trafficking as defined in national legislation. The investigating authorities ignored that Elisabeth Kawogo might have been subjected to slavery, servitude, or forced labour.

\section{Defining the Crimes of Slavery, Servitude, Forced Labour and THB at National Level}

Even if states have incorporated the crimes of slavery, servitude and forced labour at a domestic level, it must be also considered that Article 4 of the ECHR raises certain requirements as to the quality of their definitions. In this subsection, I respond to three questions. First, I ask whether states parties to the ECHR are required to define the national crimes intended to cover the abuses prohibited by Article 4 in a particular way. Second, since I give a negative response to the prior question, I ask whether there are any requirements identifiable in the ECtHR's case law as to the quality of the national substantive criminal law. I argue that there are. Finally, I scrutinise the national legislation of some states and test it against the ECHR's standards.

\subsection{Are States Required to Define National Crimes in a Particular Way?}

The ECtHR's judgment of MC $v$ Bulgaria is an appropriate starting point for addressing this question. For the purposes of this article, MC v Bulgaria is of relevance because in this case the Court was faced with the question whether states might be required to adopt certain definitions of certain crimes at the national level. ${ }^{92}$ In MC $v$ Bulgaria, the issue of the definition of the crime

were incorporated in the national legislation. Thus, the complaints raised by Elisabeth Kawogo concerned a 'historical' problem.

${ }^{92}$ MC v Bulgaria (2005) 40 EHRR 20, para 153. The case was about a fourteen-year-old girl who claimed that she had been raped by two men. The national investigation came to the finding that there was insufficient proof that she had been compelled to have sex. At the national level it was concluded that there was no sufficient evidence that force had been used and that the girl had manifested some physical resistance. The ECtHR found that Bulgaria was in violation of its positive obligations under Article 3 and Article 8 of the ECHR due to the restrictive 
of rape was under scrutiny. The applicable Bulgarian legislation criminalised rape. Moreover, the wording of the Bulgarian legal provisions did not differ significantly from the wording found in other states. ${ }^{93}$ The problem, however, laid not in the wording but in the interpretation of the national law by the national authorities: 'What is decisive, however, is the meaning given to words such as "force" or "threats" or other terms used in legal definitions.9 "The ECtHR found that the Bulgarian investigating authorities assumed that in the absence of violence and resistance, lack of consent could not be inferred and therefore the crime of rape was not constituted. Thus, in practice, the requirement for resistance was elevated to the status of a necessary element in the definition of rape under the national law. Ultimately, the Court found that Bulgaria had failed to fulfil its positive obligation to 'establish and apply effectively a criminal-law system punishing all forms of rape and sexual abuse.95 It determined that 'member States' positive obligations under Article 3 and 8 of the Convention must be seen as requiring the penalisation and effective prosecution of any non-consensual sexual act, including in the absence of physical resistance by the victim. ${ }^{96}$

Therefore, MC $v$ Bulgaria can be read to the effect that physical resistance should not be made a necessary element for the purpose of prosecuting rape. Rather, the lack of consent should be the core element. However, in $M C v$ Bulgaria, the ECtHR did not instruct how the criminal offence should be defined and formulated in the national legislation. ${ }^{97}$ The Court was very careful about how it framed the implications for the national criminal law flowing from the positive obligations under the ECHR. It did not say that the crime of rape had to be formulated and worded in a certain manner at national level. The cases of Siliadin, $C N$ and $V v$ France and $C N v$ United Kingdom confirm the above conclusion. The ECtHR was interested in how the national crimes were interpreted and the effects of the adopted interpretations in the particular circumstances. ${ }^{98}$ It did not

interpretation of the crime of rape.

${ }^{93}$ Ibid, para 74. The concrete formulation of the crime of rape at the national level was as follows: 'sexual intercourse with a woman (1) incapable of defending herself, where she did not consent; (2) who was compelled by the use of force or threats; (3) who was brought to a state of helplessness by the perpetrator.'

${ }^{94}$ Ibid, para 171.

${ }^{95}$ Ibid, para 185.

${ }^{96}$ Ibid, para 166.

${ }^{97}$ P Asp, 'MC v Bulgaria: A Swedish Perspective' (2009) 54 Scand Stud in L 191, 202.

${ }^{98}$ I do envision circumstances when the ECtHR could say that the particular national definition of a crime gives rise to a violation. For example, in relation to $C N v$ The United Kingdom if the 
prescribe how they should be defined.

\subsection{Ambiguous Framing of Crimes}

Yet, states could be in breach of Article 4 when definitions of crimes are ambiguous. In Siliadin and $C N$ and $V v$ France the ECtHR took notice of the framing of the national criminal law in relation to its ambiguity. The national criminal law provisions were open to very different interpretations from one court to the next. Different courts could interpret differently the meaning of 'vulnerability', 'dependency' and incompatibility with human dignity. This was one of the reasons for the ECtHR to conclude that national criminal law could not permit effective prosecution of servitude and forced labour.

In conclusion, the national criminal law has to be armed with sufficiently clear definitions which ensure effective investigation and prosecution of abuses falling within the material scope of Article 4. Precise provisions have to be available for the investigatory authorities and for the courts so that they can determine the facts easily, and where necessary investigate, prosecute and convict.

\subsection{The Framing of the Crimes of THB, Slavery, Servitude and Forced Labour at National Level}

Have states lived up to the above standard? A review of the national crimes which are intended to address abuses falling within the material scope of Article 4 follows. The review is conducted in two stages. The first stage covers the crime of THB. The second covers the crimes of slavery, servitude and forced labour.

\subsubsection{Human Trafficking}

The definition of human trafficking in the Council of Europe Trafficking Convention has been directly reproduced in the criminal legislation of many states. ${ }^{99}$ In this subsection, I argue that directly copying the international law

UK criminal law explicitly said that subtle forms of coercion were irrelevant for the purposes of finding a person guilty of the crime of forced labour, then the wording would be problematic.

${ }^{99}$ Many states have simply incorporated the international law definition of THB without defining exploitation, slavery, servitude and forced labour in their criminal legislation. See GRETA reports, above n 82, Croatia Report (2011) paras 34-5; Denmark Report (2011) paras 44-5; Slovak Republic Report (2011) para 36. It has been reported that the direct incorporation of the international law definition of THB in Poland has led to uncertainty and complications since 
definition of human trafficking in the domestic criminal law is highly problematic from the perspective of guaranteeing clear definitions of crimes for the purposes of effective investigation and prosecution. The international law definition of human trafficking contains elements ('exploitation', 'deception', 'abuse of position of vulnerability') which are ambiguous and, therefore, it might be difficult for a criminal court to convict an alleged perpetrator for human trafficking without entering into serious interpretation problems. This was precisely the situation faced by the UK Court of Appeal in $R v S K .{ }^{100}$ The judge could not give proper instructions to the jury as to the meaning of 'exploitation' so that the jury could decide whether K, who arranged the arrival of MM in the United Kingdom from an African country in order to work for her as a housekeeper, should be convicted for human trafficking. For that reason, the Court of Appeal found the conviction to be unsafe and held that:

[w]e do not think that, when read fairly as a whole, the judge's summing-up provided the jury with a proper definition of exploitation for the purposes of Section 4 of the 2004 Act. In describing the ingredients of the offence the judge did not identify and explain the relevant core elements of Article 4 [of the ECHR]. In our judgment, he focused too much on the economics of the relationship between the appellant and the complainant, thus diluting the test the jury had to apply to one appropriate to an employment law context but not strong enough to establish guilt of the criminal offence with which the appellant was charged. [...] What the jury had to concentrate on in this case was not the fact that the complainant was paid 'a mere pittance' or an 'exploitative' wage, but whether, when the appellant arranged for the complainant to come to the United Kingdom, she had intended to exploit her in such a way as would violate her rights under Article 4 [of the ECHR]. ${ }^{101}$

the national authorities have to use terms and notions with unclear meaning and foreign to the domestic legal system. See C Nowak, 'The Europeanisation of Polish Substantive Criminal Law: How the European Instruments Influenced Criminalisation in Polish Law' (2012) 3 New J Eur Crim L 363, 378-9.

${ }^{100} R v$ SK [2011] EWCA Crim 1691. See also A Ashworth, 'Trafficking People for Exploitation: Arranging Individual's Entry into United Kingdom with Intention to Exploit' (2012) 1 Crim LR 63.

${ }^{101} R v$ SK [2011] EWCA Crim 1691, para 44 (Justice Lindblom). 
Therefore, national legislation which has incorporated the concept of 'exploitation' as an element of the crime of human trafficking without further defining it, might not be compatible with the standards established in the ECtHR case law. ${ }^{102}$ As suggested by the UK Court of Appeal, 'exploitation' could be defined with reference to the concepts of slavery, servitude and forced labour. ${ }^{103}$ Importantly, the latter cannot be simply left undefined in the national substantive criminal law either.

In conclusion, a simplistic incorporation of the international law definition of THB leads to inadequacies. This definition was crafted in a particular legal context, namely transnational organised crime, which pursues its own particular objectives. ${ }^{104}$ It might be appropriate for human rights law to endorse the same international definition. However, as explained in Section 3, national criminal law has to live up to different standards.

\subsubsection{Slavery, Servitude and Forced Labour}

Since many Council of Europe member states do not have the specific criminal law labels of slavery, servitude and forced labour, in order to prosecute abuses falling within the scope of Article 4, they need to resort to other labels. These other labels could be human trafficking, ${ }^{105}$ deprivation of liberty, coercion or,

\footnotetext{
${ }^{102}$ Many national jurisdictions have incorporated the term 'exploitation'. See, e.g., GRETA reports, above n 82, Austria Report (2011) paras 30-1. Pursuant to Article 104(a)(3) of the Australian Criminal Code, 'exploitation' is defined as 'sexual exploitation, exploitation through organ transplantation or labour exploitation'.

${ }^{103}$ This approach has been followed by the UK courts when applying the crime of human trafficking. See $R v$ Siwak (Portsmouth Crown Court, Case No T20120208, 22 February 2013).

${ }^{104}$ The main objective of transnational organised crime is efficient international cooperation:

the main reason for defining the term 'trafficking in persons' in international law was to provide some degree of consensus-based standardisation of concepts. That, in turn, was intended to form the basis of domestic criminal offences that would be similar enough to support efficient international cooperation in investigating and prosecuting cases.

Legislative Guides for the Implementation of the United Nations Convention against Transnational Organized Crime and the Protocol Thereto, UN Office on Drugs and Crime Division for Treaty Affairs (2004) 269. See also The Explanatory Report to the Council of Europe Trafficking Convention, para 216.

${ }^{105}$ In the criminal legislation of some states the labels of slavery, servitude and forced labour are mentioned as elements of the definition of the crime of human trafficking. As argued above (see Section 4), this is inadequate for meeting the standards under Article 4 of the ECHR. Within this cluster, Norway and Germany can be distinguished since they have criminalised subjecting a person to slavery, servitude or forced labour. However, instead of naming the
} 
as is the case in France, 'taking advantage of persons' vulnerability or state of dependence'. Undertaking an enquiry of what crimes different states use to address abuses falling within the scope of Article 4 of the ECHR is a very arduous task. This is a task which I cannot attend to within the scope of the present article. Rather, my focus in this subsection is directed to those states which have the labels of slavery, servitude or forced labour. ${ }^{106}$ In the forthcoming analysis, I first refer to states with criminal legislation which arguably does not live up to the standards required by Article 4 of having clear definitions. Then, I refer to the national criminal legislation of states which perform better in terms of definitional requirements. The latter can be used as illustrations of better practices.

The legislation in the United Kingdom is an appropriate starting point since the specific prohibitions of slavery, servitude and forced labour were recently incorporated in the national criminal law of that country. In 2009, the UK criminalised slavery, servitude and forced labour. Section 71 of the Coroners and Justice Act states:

(1) A person (D) commits an offence if-(a) D holds another person in slavery or servitude and the circumstances are such that $\mathrm{D}$ knows or ought to know that the person is so held, or (b) requires another person to perform forced or compulsory labour and the circumstances are such that D knows or ought to know that the person is being required to perform such labour.

(2) In subsection (1) the reference to holding a person in slavery or servitude or requiring a person to perform forced or compulsory labour are to be construed in accordance with Article 4 of the Human Rights Convention [the ECHR, which prohibits a person from being held in slavery or servitude or being required to perform forced or compulsory labour].

The Coroners and Justice Act does not define the elements of slavery, servitude and forced labour. Instead, it refers to Article 4 of the ECHR, a human rights treaty meant to be applied against states. The definition of slavery under human

offences accordingly, they have relabelled them as human trafficking.

${ }^{106}$ Some states prohibit slavery, servitude and forced labour only in their constitutions. Since there are no corresponding provisions and definitions in the national criminal legislation, I do not examine these states. See e.g. Constitution of the Republic of Cyprus, Art 10; Constitution of the Republic of Latvia, Art 106. 
rights law refers to 'condition of a person over whom any or all of the powers attaching to the right of ownership are exercised'. Similarly, the definition of servitude, namely 'particularly serious form of denial of freedom involving an obligation to perform certain services and a feeling of the victim that the situation will not change and improve', refers to a condition. The definition of forced labour also delineates a condition of a person who is exacted to do work or service 'under the menace of any penalty and for which the said person has not offered himself voluntary'. For all the reasons stated in Section 3 of this article, these definitions might not be appropriate and sufficient for the purposes of criminal law.

The UK approach has been followed by Ireland. At the time of writing, Ireland is preparing amendments to its criminal legislation. One of the proposed amendments includes criminalisation of forced labour. According to the proposed legislation, forced labour is to be defined 'in line with the definition of that term in International Labour Organisation (ILO) Convention No 29 of 1930 concerning Forced or Compulsory Labour. ${ }^{107}$ It is dubious whether reproducing the ILO forced labour definition in a criminal law statute establishes an effective basis for prosecuting abuses. An argument could be anticipated that the choice of the legislators in the UK and in Ireland could have positive repercussions since any advanced interpretations endorsed by the ECtHR could be taken into account when the national criminal law is applied. Yet, this in no way diminishes the need for specifying the action elements of the crimes so that they can be effectively applied. The rights of the accused are also an important consideration in this context.

Within the Council of Europe there are states which have the criminal law labels of slavery, servitude and forced labour and have adopted more advanced definitions. In Italy, the crime of slavery is constituted when someone exerts on any other person powers and rights corresponding to ownership and when someone places or holds any other person in conditions of continuing enslavement. The Italian criminal law further specifies that:

[p]lacement or maintenance in a position of slavery occurs when use is made of violence, threat, deceit, or abuse of power; or when anyone takes advantage of a situation of physical or mental inferiority and poverty; or when money is promised, payments are

\footnotetext{
${ }^{107}$ See Criminal Law (Human Trafficking) (Amendment) Bill 2013 (Ireland).
} 
made or other kinds of benefits are promised to those who are responsible for the person in question. ${ }^{108}$

The Georgian Criminal Code also refers to the action of placing a person in conditions of slavery. More specifically, Article 143 of the Georgian Criminal Code stipulates:

[p]lacing a person in conditions of contemporary slavery shall mean the deprivation of identification documents, restriction of freedom of movement, restriction of communication with his/her family, including correspondence and telephone conversation, cultural isolation as well as forced labour in a situation where human honour and dignity are violated and/or without remuneration or with inadequate remuneration.

The criminal legislation of Azerbaijan first defines the condition of slavery: 'the partial or full possession of rights of other person treated like property'. It indicates the specific actions criminalised in relation to slavery:

[s]lave trade, i.e. forcing into slavery or treatment like a slave, slave keeping with a view to sale or exchange, disposal of a slave, any deed related to the slave trading or trafficking, as well as sexual slavery or divestment of sexual freedom through slavery, shall be punished by imprisonment of from 5 to 10 years. ${ }^{109}$

The latter is a successful drafting technique which ensures specificity of the crimes. It also ensures specificity as to the action element of the crimes.

\subsection{Lessons from the Australian Criminal Code}

In the course of this paper, an additional possibility needs to be canvassed: a scenario in which states have criminalised all the four abuses, to wit, slavery, servitude, forced labour and THB. An issue which emerges then is how to draw distinctions among them. The lack of understanding as to how the crime of human trafficking is to be related to and distinguished from other criminal

${ }^{108}$ See Penal Code (Italy), Art 600, translated in UNODC Model Law against Trafficking in Persons, UN Doc V.09-81990(E), 2009, 20.

${ }^{109}$ Criminal Code (Azerbaijan), Art 106, translated in UNODC Model Law against Trafficking in Persons, UN Doc V.09-81990(E), 2009, 20. 
offences has already been reported. ${ }^{110}$ Additional aggravation emerges from Anna Gallagher's suggestion that human trafficking has to be expansively interpreted so that it can encompass not only the process which could potentially lead to exploitation, but also the actual abuses. ${ }^{111}$ Thus, there could be at least two sources of insecurity: (i) what are the action elements of, for example, the crime of slavery, and how are they different from the action elements of the crime of human trafficking; and (ii) how could the distinctions between the above mentioned crimes be formulated.

In light of the above outlined obscurity, I find it useful to refer to the Australian Criminal Code, which can be assessed as containing very advanced criminal law legislation on slavery, servitude, forced labour and THB. It is praiseworthy not only for its definitions, but for its well-articulated distinctions between the different crimes. The latter is of significance because if abuses against migrants are articulated based on offences which are 'obscurely defined and chaotically distinguished', this situation is prone to create gaps and confusion. ${ }^{112}$

The Australian Criminal Code defines the conditions of slavery, servitude and forced labour. ${ }^{113}$ These definitions are very much in line with the definitions endorsed by the ECtHR under Article 4. In addition to defining the conditions of slavery, servitude and forced labour, the Australian Criminal Code Act indicates the actus reus of the crimes: reducing a person to slavery, exercising any of the powers attaching to the right of ownership, engaging in slave trading, entering into a transaction involving a slave, ${ }^{114}$ causing another person to enter into or remain in servitude, causing another person to enter into or remain in forced labour, conducting a business involving servitude, or conducting a business

\footnotetext{
${ }^{110}$ See GRETA reports, above $\mathrm{n} 82$, Norway Report (2013) paras 39-40 (the distinction between THB and slavery/forced labour); V Roth, Defining Human Trafficking and Identifying its Victims: a Study on the Impact and Future Challenges of International, European and Finnish Legal Responses to Prostitution-related Trafficking in Human Beings (2012) 167-80 (the distinction between THB and pandering); D B Jansson, Harmonizing National Laws on Human Trafficking by Implementing Article 3 of the Palermo Protocol: Problems and Reform (PhD Thesis, Uppsala University, 2013).

111 '[M]aintaining an individual in a situation of exploitation through any of the stipulated means would [...] also amount to trafficking.': A Gallagher, The International Law of Human Trafficking (2010) 30 .

${ }^{112}$ See Tadros, above n 79, 81

${ }^{113}$ See Criminal Code Act 1995 (Cth) s 270.1. The slavery offence was introduced in the Australian criminal law in 1991. See Criminal Code Amendment (Slavery and Sexual Servitude Act) 1999 (Cth). For application of the slavery definition, see $R v$ Tang [2008] HCA 39; Hov $R$ [2011] VSCA 344; Ho v R [2012] HCATrans 199.

${ }^{114}$ Criminal Code Act 1995 (Cth) s 270.3.
} 
involving forced labour. ${ }^{115}$ For a person to be convicted for these crimes, the prosecution is required to prove that the victim was in a condition of slavery, servitude or forced labour, and that the defendant intentionally engaged one of the above enumerated actions. ${ }^{116}$

The criminalisation of slavery, servitude and forced labour as set out in the Australian Criminal Code Act was an object of gradual development. ${ }^{117}$ For example, the action of reducing a person to slavery was not initially included. Subsequently, it was realised that the offences of exercising any of the powers attaching to the right of ownership, engaging in slave trading, entering into a transaction involving a slave 'may have the unintended result of requiring the prosecution to prove the victim was already in a state or condition of slavery at the time the offender possessed, exercised the power of ownership over, or entered into a transaction involving the victim. ${ }^{118}$

The action of reducing a person to slavery was included so that the above concern can be addressed. In this way, a person who renders another person a slave can be held criminally responsible for slavery. ${ }^{119}$

How does the Australian legislation compare with the legislation in the United Kingdom, which was relatively recently adopted and which is likely to serve as an example for other Council of Europe states? Pursuant to Section 71 of the Coroners and Justice Act, the action criminalised is holding another person in slavery. This formulation is directly copied from Article 4 of the ECHR. In relation to the action of 'holding', the Ministry of Justice Circular has clarified that: "[i]f labour is subcontracted to another company and the employees of that other company who do the work are held in slavery or servitude or are required to perform forced or compulsory labour, then the subcontractor is the principle

\footnotetext{
115 Ibid, ss 270.5, 270.6A.

${ }^{116}$ Crimes Legislation Amendment (Slavery, Slavery-like Conditions and People Trafficking) Bill 2012 (Cth), Addendum to the Explanatory Memorandum (2012), 3.

${ }^{117}$ See Crimes Legislation Amendment (Slavery, Slavery-like Conditions and People Trafficking) Act 2013 (Cth).

${ }^{118}$ Ibid, Explanatory Memorandum (2012), 13. For other relevant documents related to the bill see <http://www.aph.gov.au/Parliamentary_Business/Bills_Legislation/Bills_Search_Results/Result?bId=r4840> [accessed 19 March 2014].

${ }^{119}$ For an overview of other amendments introduced in the Australian criminal legislation in relation to the crimes of slavery, servitude and forced labour see Bills Digest No 14, 2012-13, Crimes Legislation Amendment (Slavery, Slavery-like Conditions and People Trafficking) Bill 2012 (Cth), <http://parlinfo.aph.gov.au/parlInfo/download/legislation/billsdgs/1869207/upload_binary/1869207.pdf;fileType=application\%2Fpdf\#search=\%22legislation/billsdgs/1869207\%22> [accessed 19 March 2014].
} 
offender.' ${ }^{\prime 20}$ In contrast, if the action specifically referred to in the UK legislation were not only holding, but also rendering/reducing another in slavery, then not only the subcontractor's conduct, but the abusive practices of the agencies that make workers available to companies could be an object of investigation. Thus, besides the action of holding another person is slavery, the action of reducing a person to slavery should be also considered for inclusion. Clearer formulation of the required action elements is desirable. Simplistic reproduction of the text of Article 4 of the ECHR in national criminal legislation is insufficient.

In addition to criminalising slavery, servitude and forced labour and clearly setting out the elements of the respective crimes, the Australian Criminal Code Act contains a separate offence of trafficking in persons. ${ }^{121}$ The action elements of the latter offence are organisation or facilitation of the entry or proposed entry or receipt of another person in Australia. ${ }^{122}$ In this way, the crime of human trafficking is clearly distinguished from the crimes of slavery, servitude and forced labour. Thus, human trafficking is about the organisation of a person's movement. This formulation is in line with the international law origins of the concept of human trafficking. ${ }^{123}$ Accordingly, the above mentioned suggestion by Gallagher which favours the recasting of abuses as human trafficking even when the perpetrator is not involved in the facilitation of the person's movement is dubious and leads to unnecessary confusion.

\subsection{Conclusion}

Siliadin and $C N$ and $V v$ France point out that states can be in breach of their positive obligations under Article 4 of the ECHR if the national crimes meant to address abuses are vaguely framed and, thus, difficult to apply for the purposes of effective investigation and prosecution. I demonstrated that states which have directly incorporated the international law definition of human trafficking, without further defining the elements of the crime, risk breaching their obligations under Article 4 of the ECHR. As the judgment of $R v S K$ suggests,

\footnotetext{
${ }^{120}$ Ministry of Justice Circular 2010/07 'Slavery, Servitude and Forced or Compulsory labour: Implementation of Section 71 of the Coroners and Justice Act 2009, Ministry of Justice Circular 2010/07', in P Chandran (ed), Human Trafficking Handbook: Recognizing Trafficking and Modern-Day Slavery in the UK (2011) App 11.

${ }^{121}$ Criminal Code Act 1995 (Cth) Div 271.

${ }^{122} \mathrm{Ibid}, \mathrm{s} 271.1$.

${ }^{123}$ Protocol to Prevent, Suppress and Punish Trafficking in Persons, Especially Women and Children, Supplementing the United Nations Convention Against Transnational Organized Crime, 8 January 2001, 2237 UNTS 319.
} 
the international definition of human trafficking is highly insecure as to the required elements and the required thresholds. I also demonstrated that states cannot simply reproduce the definitions of slavery, servitude and forced labour as utilised by the ECtHR for the purpose of establishing state responsibility when applying Article 4 of the ECHR. Finally, I submitted that states might be found in violation of their obligations under Article 4 not only when national crimes are obscurely defined, but also when they are chaotically distinguished. At this junction, I found it useful to refer to the Australian criminal legislation. The latter is exemplary not only for its definitions of slavery, servitude, forced labour and human trafficking, but also for its well-articulated distinctions between the different crimes.

\section{Conclusion}

It has been widely reported that the number of prosecutions and convictions for THB and for slavery, servitude and forced labour, where the latter have been specifically criminalised, is low. As a reaction, it has been suggested that the definitions of these crimes have to be expansively construed. These proposals ignore the basic criminal law precepts. Criminal law has to remain faithful to the principle of legal certainty and to the rights of the accused which ban expansive interpretations. It is human rights law which celebrates liberal interpretations of concepts for the purpose of holding states internationally responsible for their failures to protect individuals.

In this article, I demonstrated how the different interpretative standpoints of human rights law and criminal law apply in relation to the abuses of slavery, servitude, forced labour and THB. From the perspective of human rights law, when asking the question whether the state has failed to ensure the human rights of migrants not to be subjected to abuses, expansive interpretation of the concepts of slavery, servitude, forced labour and THB can be celebrated. This is intimately linked to the reasons for which we undertake the enquiry. We are interested in the overall situation of the victim and the abuses which he/she has suffered irrespective of who inflicted those abuses and what intention each specific perpetrator had in mind. In the context of human rights law, we are to inspect the broader circumstances of the victim's situation. The focus is on the overall conditions surrounding the victim, and whether these conditions amount to abuses falling within the scope of Article 4. In contrast, from the perspective of criminal law, the actions of the individual defendants need to be scrutinised. 
It needs to be determined whether they correspond to the action elements of the respective crimes. When this latter enquiry is undertaken, the objective is establishment of individual criminal responsibility, and the restraints of the criminal law interpretative tools need to be taken seriously.

I also underscored that for the purposes of applying some of the positive human rights obligations as developed by the ECtHR, it is not even necessary to demonstrate that the migrant's circumstances qualify as slavery, servitude, forced labour or THB. For example, the triggering of the procedural limb of Article 4 (the positive obligation of investigating) requires reasonable suspicion that a migrant has been subjected to abuses.

Instead of proposing interpretations which sit at odds with the interpretative methodology applied in the realm of criminal law, I suggested that more efforts should be invested in understanding the implications from the positive human rights obligation of criminalising abuses falling within the material scope of Article 4. I focused on the following implications. First, Article 4 of the ECHR obliges states to specifically criminalise slavery, servitude and forced labour, an obligation which many states have failed to fulfil since the focus has been predominantly placed on the criminalisation of THB. ${ }^{124}$ This leads to failures to address abuses where there are no elements of, inter alia, recruitment, transportation, transfer by means of deception/coercion.

Second, Article 4 of the ECHR obliges states to incorporate in their domestic criminal laws sufficiently clear definitions of crimes intended to address the abuses falling within the scope of Article 4. As demonstrated by Siliadin and $C N$ and $V v$ France, when crimes are vaguely framed, it is difficult to apply them for the purposes of effective investigation and prosecution. I argued that states cannot live up to the above mentioned obligation when they directly copy the international law definition of human trafficking. This definition was crafted in a legal context, namely transnational organised crime, with certain goals distinct from the precepts of national substantive criminal law and it is rife with ambiguities. Similarly, states cannot simply reproduce in their domestic criminal laws the definitions of slavery, servitude and forced labour as used by human rights law. Human rights law and the ECHR are applied for the purpose of establishing state responsibility. In contrast, national criminal law is applied for the purpose of establishing individual criminal responsibility. For the purpose

\footnotetext{
${ }^{124} \mathrm{My}$ arguments should not be interpreted to the effect that I am a proponent of the extension of criminalisation. Article 4 of the ECHR imposes additional positive obligations which extend to other areas of the national regulatory framework. These positive obligations are an object of my current work.
} 
of convicting perpetrators, the requisite action elements of the crimes need to be specifically indicated in the national criminal legislation.

Finally, I submitted that states might be found in violation of their obligations under Article 4 of the ECHR not only when national crimes are obscurely defined, but also when they are haphazardly distinguished. The distinctions between the different crimes need to be well articulated to address the abuses falling within the ambit of Article 4. The Australian Criminal Code Act serves as a helpful model for this purpose. 